\title{
The physical treatment and rehabilitation of osteoporosis
}

\author{
D Marchese \\ From de Senectute: Age and Health Forum \\ Catanzaro, Italy. 5-7 December 2009
}

Osteoporosis is a "disease characterized by decreased bone mass and deterioration of bone microarchitecture with consequent increase in bone fragility and fracture risk" (Consensus Develop Conference). Numerous studies have shown that even if Osteoporosis is a disease of old age, it finds its roots in the paediatric age: the amount of bone tissue depends on the skeletal assets that people acquire on the pinnacle of somatic development. It follows, therefore, that the importance of prevention should begin, in fact, right from pre-natal age. Prevention relies on a multidisciplinary program which should include education, adaptive changes of environment with possible home visits, assistance through a Physiatric counseling with patients and their families and implementing a program of individual exercise. Therapeutic exercise remains the cornerstone of the rehabilitative approach and its rational use in osteoporotic patients lies on its ability to cause a mechanical stimulation of the bone to allow an effect on bone remodeling in the sense of osteoblast stimulation. There are many studies that have sought a correspondence between physical activity and BMD. Osteoporosis should always be considered a preventable and treatable disease. His treatment relies not only on drug therapy. Therapeutic excercises, although of undoubted value, is indeed set in the context of a more open-minded multidisciplinary program that includes food and behavioral hygiene, and specific therapeutic exercises, orthesis, up to the surgical treatment, that often represents the treatment in emergency fractures. The data in literature gives great importance to the young age, as the most suitable age to begin the physical activity because it is thus possible to reach a higher bone mass peak. Several studies show that prevention with physical activity should even start in an adolescent age to actually continue

Postgraduate Course in Physical Medicine and Rehabilitation - Università Magna Graecia - Catanzaro, Italy throughout the life period. A continuous physical activity regularly managed, avoids the collapse of bone mass that occurs after menopause. It is also fundamental not to suspend physical activity and to not return to baseline levels. In setting up a physiotherapy job we can apply multiple objectives. In this sense we can recognize as a primary endpoint the bone mass increasing (pursued through direct mechanical stimulation, use of local loads, improving aerobic capacity, strengthen muscles, using the force of gravity) and as a secondary objective the prevention of fractures (pursued through the improvement of balance and coordination, increasing of soft tissue trophism, the 'postural and ergonomic education to improve the range of motion).

Published: 19 May 2010

doi:10.1186/1471-2318-10-S1-L68

Cite this article as: Marchese: The physical treatment and rehabilitation of osteoporosis. BMC Geriatrics 2010 10(Suppl 1):L68.

Submit your next manuscript to BioMed Central and take full advantage of:

- Convenient online submission

- Thorough peer review

- No space constraints or color figure charges

- Immediate publication on acceptance

- Inclusion in PubMed, CAS, Scopus and Google Scholar

- Research which is freely available for redistribution

Submit your manuscript at www.biomedcentral.com/submit
Ciomed Central 